\title{
Management and Society
}

\author{
Francisco Tulop Roma ${ }^{1, *}$ and Bernardo Jeffrey Ladao Morante ${ }^{1}$ \\ ${ }^{1}$ School of Business and Economics, Tan Tao University, Duc Hoa, Long An, 850000, Viet Nam.
}

\begin{abstract}
Management existed as early as mankind. It has a biblical foundation and reference. It has been practiced for thousands of years and organized projects were directed by people responsible for planning, organizing, leading and controlling. Management theories and practices evolved in the past showing the evolving nature and character of management. Early management scholars and contributors recognized the existence of the three approaches of management which are classical approach, behavioural approach and integrative approach. This research article presents the evolving nature of management thoughts and practices from the early approaches of management to modern approaches to management. This in effect would give the much clearer understanding of hundreds of definition of management ranging from simple to complex. And that management is not only the process of getting things done effectively and efficiently, with and through people but it also has become
\end{abstract} a social institution. Hence, it cannot escape social issues.

DOI: https://doi.org/10.53901/alqp2jh779|

\section{KEYWORDS}

Behavioural Science

Evolution

Management

Society

Theories

\section{ARTICLE HISTORY}

Received: 15.07 .2020

Accepted: 01.08.2020

Online: 10.08 .2020

\section{INTRODUCTION}

Given the premise that management is an inexhaustible subject to deal with, this paper presents a brief overview of the field of management. This article is an attempt to describe in broad terms the evolving nature of management and the streams of thought (i.e., ideas and theories) that contributed to its development. The paper is an attempt to draw out an introductory understanding of what management is and the attendant development of management thought.

The materials used in this paper are drawn from the list of references (See Bibliography). A short survey presented by these references shows management is a subject faced with the continuous process of having to accommodate new ideas that spring from many new sources. Management thought continually requires restatement and consolidation. As one writer has it, management is a synergistic field of human endeavour.

\section{HISTORICAL OVERVIEW OF MANAGEMENT}

\section{Nature and Roots of Management}

Management is an ancient art, as ancient as mankind. Management [1] is a science that dates back to centuries. It is one such concept that existed from 2900 BC in Egypt. Management thought [2]

Dedicated the 10th Anniversary of Tan Tao University was initially of interest to political theorists. That is, in ancient Greek and Biblical times, problems of administration were of interest to students of government.

Biblical narratives are replete with human dramas that reflect organization problems. A case in point was the long struggle of Moses in leading his people out of bondage and into the promise land. The case of Solomon depicts a classical situation of decisionmaking, a judgment of compromise where both mothers would be in a no-win situation over claims in conflict for the custody of the child. This is later an oft-quoted wisdom in judgment, viz., Solomon wisdom. Likewise, histories of the Roman Empire contain information on how administrative problems were handled.

During the ancient times, however, no important tools of analysis were developed, not until the end of the Dark Ages, when commerce began to grow in the Mediterranean. In the middle ages, the family unit was the basic production organization. Production functions were not distinguishable from social functions. That is, managerial activities were not a separate area of concerns from the family. It was the inventions of the 18 th century that brought about an initial change, ultimately resulting to a clear demarcation line between production and social function. This period is called by the historian Toynbee the "Industrial Revolution." Production moved from the home to a separate installation - the factory. At the early stages of this era, owners of factories still directed pro- 
duction; there was no distinction between the ownership functions and management duties. It was during the early part of the 19th century when ownerships of production and managerial activities split into some kind of parallel paths. The need for larger aggregation of capital to support factory operations gave rise to an increase in the application of a special legal form of organizing a business, namely, the use of corporation. As a legal entity, the corporation could sell shares of stock to many individuals, raising large sums of capital. Subsequently, as stockholders became numerous all could not actively manage a business. By the middle of the 19th century, general incorporation acts made it possible for many businesses to use this legal form of organization, at a time in which technological developments were forcing an increase in the size of the manufacturing unit. The corporation provided the means by which capital could be secured for owners who were not managers. The distinction between the function of owners and the function of managers became clear and distinguishable. This distinction set the stage for students to concentrate on the management process as a separate field of study. With the advent of the Industrial Revolution the interest began to focus around the factory and mechanical production. Attention was focused in the field of economics viz., Adam Smith's The Wealth of Nations, which he wrote in 1776, emphasizing economic concepts such as the "division of labour." The development of the factory system resulted in an increased interest in the economics of production and the entrepreneur. While the problems encountered were similar to that of the early ages, human nature seemingly immutable, new solutions were needed. Thus, prior to the beginning of the 20th century, the essential elements or seeds were already present for the emergence of systematic management thought.

In 1832, scientists and other persons not directly related to ownership of manufacturing firms began to consider improvements in management. Charles Babbage (mathematician and teacher) wrote "On the Economy of Machinery and Manufactures." He introduced the idea of using scientific techniques to improve the managing process. The concern was still narrow in scope, as it excluded yet the social, legal, technical, and economic environment.

Some schools of thought related to the field of management theory are worth discussing. These are a) structuralism (bureaucracy, functionalism, and scientific management), b) behavioural sciences, and c) decision theory. Research study of Kwok [3] pointed out that management theories had become more multi-faceted where emphasis has shifted from behavioural science to organizational structures and quality assurance.

Structuralism Structuralism's viewpoint considers the roles people perform and the structure within which they perform them rather than the individual personalities accomplishing the roles. The best known structuralism theorist was Max Weber (a German sociologist). His primary contribution was to explain and refine the concept of bureaucracy. Other structuralism theorists were Frederick W. Taylor (an American), considered to be the father of scientific management, and Henri Fayol (a French industrialist). The emergence of structural theory (structuralism) may be said to be as follows:

Organizations rely on the accomplishment of certain tasks and activities as a means of goals. The regularity of activity, e.g., exercise of authority, task accomplishment, and the coordination of various organizational and managerial functions, is essential. As systematic management developed, three groups of structuralism theorist emerged, with interest in the various aspects of this regularity, namely, a) bureaucracy (concerned about the nature of organizational authority), b) scientific management (concentrated on the design of work and task accomplishment) and, c) functionalism (concerned and attempted to analyse the manager's job and improve the administration of formal organization).

Collectively, these three groups are referred to as the three main lines of thought known as structuralism. Structural theory dominated management theory and practice for more than three decades, viz., Weber's sociologically based theory of bureaucracy, Fayol's practical analysis of administrative processes, and Taylor's engineering-oriented scientific management.

Bureaucracy Max Weber's theory of bureaucracy management focuses on ideal structure of an organization. Formal rules is the basic principle of bureaucracy [4]. Weber's primary contribution to management is his theory of authority structures and his formulation of organizations according to the nature of authority relations within them. There are three types of legitimate authority: a) rational-legal authority (obedience is owned to a legally established position or rank with the hierarchy of business, military unit, government, and so on), b) traditional authority (obedience is due a person because he belongs to a certain class or occupies a position traditionally recognized as possessing authority, e.g., royal family), and c) charismatic authority (obedience is based on the followers' belief that a person has some special power or appeal). Bureaucracy is a theoretical model or ideal of a class of organizations displaying characteristic as: 1) division or specialization of labour, 2) a well-developed hierarchy, 3) a system of procedures and rules by which the rights and duties of employees are defined, 4) interpersonal relations based on positions rather than personality, and 5) promotion and selection based on technical competence.

As a theoretical model or ideal organization, bureaucracy was designed to emphasize objectivity and proven competence rather than subjective favours.

Functionalism The functional theory is also classified as a process approach. According to this line of thought, all administrators perform certain types of functions: planning, organizing, controlling, being the most general. Management is the process of performing these functions. Thus, all managers do essentially the same thing. This suggests the universality of management functions. The assumption is associated with the idea of the transferability of management skills.

Functionalism concentrates on the roles a manager performs: as a planner, organizer, and controller. The objective is to formulate principles or guides to assist managers in performing these functions. The elements of functional theory are reflected in Fayol's classification [2] of business operations in six headings, namely: 1) technical (production), 2) commercial (purchase and sales), 3) financial (funding and controlling capital), 4) security (protection), 5) accounting (balance sheet, costing, records, and 6) administrative (planning, organizing, commanding, coordinating, and controlling. Fayol enunciated certain principles or guidelines: a) division of work - the economic concept of the specialization of labour, both technical and managerial, b) authority - the right to give orders and the power to exact obedience, c) discipline - based on good leadership, clear agreements between management and workers, and judicious use of punishment, d) unity of command - each employee receiving orders from only one superior, e) unity of direction - one head and one plan for a group of activities having the same objective, f) subordination of individual interests to the general interests - to reduce individual and group conflicts with the larger organization, g) remuneration - to make personnel more valuable and to encourage high level of quality work, h) centraliza- 
tion - one of proportion: anything that increased the importance of the workers' role (such as participation in decision making) was decentralization; anything that reduced their importance was centralization; thus, it should be one of proportion, depending on the demand of each unique case, i) scalar chain - the chain of command, the flow of managerial rights, from the top to the bottom of the organization, j) order - all materials and personnel in the place where they were supposed to be as prescribed by the organization structure, k) equity - based on justice in employeemanager relationships, l) stability of tenure of personnel - requires planning of personnel needs, $\mathrm{m}$ ) initiative - individuals to exert energy and enthusiasm in all their undertakings, and n) esprit de corps - harmony in the organization.

Behavioural Sciences It is the field of study concerned with the systematic examination of human behaviour. This field is constituted by a) anthropology (concerned with the effects of culture and other factors on the development of human behaviour and social structure), b) economics (concerned with insights into the nature of rational human choice), c) psychology (concerned with and encompasses theories of human needs and their relationships to motivational systems and deals with numerous other topics with implications for management), d) sociology (deals with theories of large and small group behaviour), and e) political science (deals with the governance of complex organizations).

The primary focus of the social and behavioural scientists is on the individual and on his interaction in the group. They likewise focus on what motivates human behaviour, the relationship of individual and the achievement of organizational goals, the actions of men-in-organizations, viz., leadership processes and social groupings. One of the known behavioural scientists,

Kurt Lewin, developed the theory and research under the heading of "group dynamics." His study of small groups led him and his followers to concentrate on the advantages of group participation and increased interaction among members of a group.

Decision Theory The main thrust of this theory is to combine the natural and behavioural sciences in a quantitative or mathematical systems or approach. It is the application of the systems concepts to management and the importance of organizations adapting to environment pressures. This theoretical outlook has similarity with the orientation of the "contingency theory." The decision theorists contributed to the idea of systems theory in management and were concerned with the decisions making process in organizations, as they view the firm an information processing system. They applied economics and psychology and computer science to the problems of management and organization theory. They view organization is not an entity pursuing a single goal but a coalition of the interests of owners, consumers, employees and managers all having differing preferences about the goals of the firm.

Contingency Theory One of the outgrowths of the systems perspective is the contingency theory. Its central thesis is that there are no universal principles of management applicable to all situations. Management approaches must vary from one firm to the next because it depends on the unique environmental conditions and internal factors which are inherent to each organization [5]. As there are no universal truths about management, the effective use of each set of ideas is contingent on its congruence with situational demands. In this premise, it stresses the reality of the "situation" faced by managers. The idea is that - there is no "one best way" to manage in all situations, taking into account the importance of situational variations. As stated in the findings and/or conclusion by Kitana [1], all theories beginning from the classical theories to bureaucratic theories and systems approach theories complete each other. Management and managers should benefit from those theories, they need to learn and know how those theories can contribute in the development process. Sometimes to manage successfully we need to merge those theories and integrate them together.

\section{Development and Shifting Focus of Management Thought}

The general usage of the word "management" connotes a special group of people whose job it is to direct effort and activities of other people toward common objectives. Simply stated, management "gets things done through people." Broadly, management [6] can be viewed as the activity responsible for the creation, growth, and survival of the organization. Part of its responsibility is the allocation and utilization of resources to create value or utility. The twofold purpose of management is: 1) to convert resources into value, and 2) to satisfy the needs and wants of organization members and the users of organizational outputs. The notion of management as a process means [6] a set of activities or a process for coordinating and integrating the use of resources to accomplish organizational purpose (productivity and satisfaction), through people, via techniques and information, and in an organized structure. The various basic activities of this process and the corresponding organizational elements [7] are as follows:

\begin{tabular}{|c|c|}
\hline Managerial activities & Related organizational elements \\
\hline planning & Purpose \\
decision making & Techniques \\
organizing & Structure \\
coordinating & People \\
controlling & Information \\
\hline
\end{tabular}

Traditionally, the need for management arises in order to establish authority [6] and resolve conflicts. In this sense, management is primarily responsible for coordinating the various basic elements of the organization to minimize these activity and goal conflicts. Considered as the most general classification, the managerial activities are clustered as 1) planning, 2) implementing, and 3) controlling. In the modern industrial world, management is "universal." For, every organization [2] requires the following: 1) the making of decisions, 2) the coordinating of activities, 3) the handling of people, and the 4) evaluation of performance directed toward group objectives. Thus, farm management, health management, college management, government management, marketing management, production and operations management - all have elements in common, viz., management as universal.

Management [8] is "the process by which a cooperative group directs actions toward common goals." Duncan [2] defines it as consisting "of all organizational activities that involve goal formation and accomplishment, performance appraisal, and the development of an operating philosophy that ensures the organization's survival within the social system." In terms of effect, it is the basic integrating process of the organizational activities that surround our daily life, the coordination of all resources through the process of planning, organizing, directing, and controlling in order to attain stated objectives. The chief characteristic of management is the integration and application of the knowledge and analytical approaches developed by numerous disciplines, e.g., psychology, economics, accounting, sociology, and anthropology. The manager's problem 
along this line is to seek a balance among those approaches and to apply the pertinent concepts in specific situations which requires action [8]. The concentrated study of management, as a separate and distinct field of endeavour, is a product of the last century. The origin of this young discipline was the work performed by Frederick W. Taylor and his associates during the scientific management movement that developed around 1900 [9]. Before, the study of management was the use of means to accomplish a given ends; today, it includes moral and ethical questions concerning the selection of the right ends toward which managers should strive. A threefold concept for emphasizing a broader scope for the viewpoint of management is that management as a) an economic resource, b) a system of authority, and c) a class or elite [2]. As viewed by the economist, management is one of the factors of production together with land, labour and capital; the reason being that the managerial resources of a firm determines its productivity and profitability. As viewed by a specialist in administration and organization, management is a system of authority. Historically, management first developed 1) an authoritarian philosophy with a small number of top individuals determining all actions of the rank and file; 2) later, humanitarian concepts caused some management to develop paternalistic approaches; 3) still later, constitutional management emerged, characterized by a concern for definite and consistent policies and procedures for dealing with the working group, and 4) as more employees received higher education, the trend of management was toward a democratic and participative approach. Modern management can be viewed as a synthesis of these four approaches to authority.

As viewed by a sociologist, management is a class and status system. The increase in the complexity of relationships in modern society demands managers become an elite of brains and education. Entrance into this class is based more and more on education and knowledge, instead of on family or political consequences. Some view this development as a "managerial revolution" in which the career management class obtains increasing amounts of power and threatens to become an autonomous class. A narrow perspective, management is viewed as striving only toward efficiency, profitability, and effective human relations. This is considered an obsolete view. The trend is toward requiring managers to consider ethical issues, service to society, and other characteristics of a profession. A liberal point of view, the total concept of management requires an understanding of the meaning of liberal education and its relationship to management functions. Its emphasis: on freedom to choose from the widest range of possibilities by discovering new possibilities, and by recalling possibilities previously developed but forgotten. Because management must be concerned with ends as well as means, it must maintain broad perspective, unfettered by specialized restriction. The paradox of management: it is based on identifiable and rigorous framework of concepts, but at the same time it continues to strive toward breaking out of any set of discipline. On the foundations and approaches to management theory, contributions from a variety of disciplines have left their mark on the development of modern administrative thought. Some ideas have come formalized within the framework of management. The five most important disciplines that contributed to management are [8]: 1) managerial economics, 2) managerial accounting, 3) quantitative disciplines of mathematics and statistics, 4) behavioural science (particularly psychology and sociology), 5) systems and computer science. The roots of management are said to be in these five fields of study.

The development of management thought over the last 100 years has not been a single continuous stream from one source but has been a process of integrating ideas from a number of streams. The shifts in focus in management thought are shown as:

1. From 1900 to 1930: the major focus was on the physical factors as viewed from industrial engineering and economics;

2. Between 1930 and 1960: the focus shifted to the human factors affecting productivity, with supporting efforts from managerial accounting and classical concepts of personnel and finance;

3. During the 1960s, as a result of reports prepared for the Ford and Carnegie Foundations, emphasis was placed on achieving precision through the use of quantitative methods (mathematics and statistics) and the behavioural sciences (psychology, sociology, anthropology). Computers and systems thinking developed rapidly during this decade as techniques for management;

4. The trend in 1970s - focus on organizational behaviour (built on the behavioural approach) as almost synonymous with management; Robbins et al [10] defines organizational behaviour as the study of what people do in organization and the way their behaviour affects the organization's performance. It focuses on three determinants of behaviour in organizations: individual, groups, and structure.

5. In the last decade, contingency theories (theories of management which are dependent upon the environmental situations in which they are applied) received major attention. The classical approach of a single universal theory of management has given way to a number of contingency theories; also, legal aspects, cultural considerations, and the emerging force of public administration received new emphasis [11].

\section{Disciplinary Bases of Management}

There are four types of management theories [5]: 1) scientific management, 2) human relations and participative management, 3) management science, and 4) visionary leadership. The early portion of this paper has dealt with partially the last three management theories. In 1886 [2] R. Towne, in his paper "The Engineer as an Economist," made a plea to the American Society of Mechanical Engineers to recognize management as a separate field of study. He was president of Yale and Towne Manufacturing Company. On that same year the paper was presented to ASME, Frederick W. Taylor was an operating manager at Midvale Steel Works. He observed that managers "pick up" their management skills through trial and error and "rule of thumb" were their only guides, and argued that too much management's job was being left to the worker. He felt that it is management's job to set up the methods and standard of work and to provide incentive for the worker to increase production. From this thinking, the ground was paved for the provisions of specific techniques for managers. Thus, his contributions led him to the recognition of "father of scientific management."

Scientific ManagementScientific Management (Taylorism) stressed that the core of scientific management was not in individual technique but in the new attitude toward managing a business enterprise. The essence of scientific management [2] was reflected in four general areas:

1. The discovery, through the use of the scientific method, of basic elements of man's work to replace the rules of thumb. 
2. The identification of management's function of planning work, instead of allowing workmen to choose their own methods.

3. The selection and training of workers and the development of cooperation, instead of encouraging individualistic efforts by employees.

4. The division of work between management and the workers so that each would perform those duties for which he was best fitted, with the resultant increase in efficiency.

During the 1920s and 1930s, scientific management fell into the hands of "efficiency experts" (who concentrated on the mechanical aspects of production). Critics of the movement pointed out that this approach neglected the elements of the psychological needs of workers and the sociological aspects of cooperation. By concentrating on the details of the shop, scientific management neglected improvements at higher level of the organization. During these decades, some management thinkers and practitioners attempted to remedy this defect. This paved the ground work for a multiple attack on the study of essentials of management.

By 1924, scientific management became international in scope. Henri Fayol had previously led a French movement in the improvement of work at the administrative level of organization. Lenin has seen the advantages of the techniques of scientific management and introduced the idea in Russia. Disciples of the movement took an aggressive mechanical view of production; and created opposition by organized labour. Scientific management pioneered the application of science to the study of management. The approach was extremely empirical, i.e., based on the experimental method of observation. It was almost exclusively concerned with the "shop level," with the primary applicability limited to production operations [2]. According to him, the mechanism proposed by Taylor (Taylor's mechanism) contained the elements:

1. Time study - through time study the precise time required for each element of a man's work was determined;

2. Differential piece-rate system - each worker was given a daily task to be completed at a specific rate and was paid a premium each time he exceeded the standard;

3. Establishing a planning department where specialists using slide rules, time-study records, and other devices would work out proper speeds for accomplishing work, supply workers with instruction cards explaining how to do work, and so on;

4. Functional foremen - act as teachers to see that workers carried out instructions; four on the floor of the shop (gang boss, speed boss, inspector, repair boss) and four in the planning room (order of work and route clerk, time and cost clerk, instruction card clerk, and disciplinarian);

5. Standardization of tools, cost systems, and several other items.

These elements constituted the mechanism by which scientific management was to function. According to Reid Sanders [9] was obsessed with efficiency. The objective of management was to secure the maximum prosperity for the employer and the employee, thus, to train each individual to do the "highest class work for which his natural abilities fit him."

Scientific management [9] adopted a mechanistic view of human behaviour. People were assumed to be alike and interchangeable and programmable; their behaviour could and should be programmed by their managers. According to this theory, 'worker' were assumed to operate in their own self-interest, including the natural disposition to 'take it easy' on their job, e.g., to restrict output in accordance of group norms or standards. Taylor's approach was to replace workers' discretion over how they do their jobs with a management that formulates the plans, makes decisions, gives orders, direct the work, and monitor the results. Scientific management reaffirms the principle of the division of labour. Tasks were simplified, managers decided on the one best way of doing each task, using data collected with objective scientific methods by time-and-motion specialists. The use of brain power was removed from the shop floor as all problem solving, decision making, and thinking became the responsibility of manager. The job of workers was to do the work, not to decide how it was to be done. Two key ingredients of the scientific management are thus: 1) separating the planning and doing of job, and 2) using economic incentives to motivate workers.

Other contributors [12] to scientific management were: Henry Gantt, Frank Gilbreth and his wife, Morris Cooke, and Harrington Emerson, among others. Gantt emphasized the psychology of the worker and the importance of morale in production. He devised a wage payment system, which stimulated foremen and workers to strive for improvement in work practices. He developed a charting system for scheduling production (the basis now for the modern scheduling techniques).

Frank Gilbreth - made studies in applying the principles of motion economy (considered to be the originator of motion study). He revolutionized the techniques of bricklaying. His wife contributed to a new dimension in her writings on the psychology of management. Both took an analytical approach and stressed the importance of giving attention to minute details of work.

Morris L. Cooke - demonstrated the applicability of scientific management in non-industrial fields, viz., university operations and city management. Harrington Emerson - introduced new ideas to Sta. Fe Railroad; later, he developed the 12 principles of efficiency.

Human relations and participative management Structural thought (classical management) placed [2] emphasis on individuals. Follett preferred society based on group principle. Also Bernard, rejecting much of competitiveness which evolved from individualism and advocated cooperative group ethic. This "group philosophy" became instrumental in weaning management theory away from individualistic ethic of structural thought and shifting it toward group concept. This paved the way for contemporary human relations management and the recognition of the place of business within a broader social system.

In 1930s, the Hawthorne's experiment: "What are the effects of illumination on worker productivity?" was considered as the origins of human relations movement in industry. The movement [9] advocated concern for the needs of workers. Satisfying workers' need will lead to high productivity. The assumption was - satisfaction causes effective performance. The experiment was conducted between 1927 and 1932, at a plant of the Western Electric Company. Elton Mayo, a Harvard sociologist, and a team of social scientists, conducted a series of experiments and worked with management in an attempt to explain variations of productivity in the plant. The physical factors (viz., lighting and working conditions) were first aspects to receive attention, but psychological factors emerged as the more important [12].

Management Science By the late 1950s, a 3rd set of managerial ideas began to take shape: a new set of technologies consisting of powerful mathematical tools have proven useful in solving war- 
related problems became available to industry. These technologies are referred to as management science, aided by the development of the computer (which became the primary tool).

As an approach, management science was intended as a means of designing and performing decision-making tasks. The aim is to maximize the quality of decisions, relative to the goals of the organization, using relevant information that is available. The approach ignored the commitment and motivation of people to execute decisions, whereas participative management focused explicitly on commitment and motivation. It shares many characteristics with that of scientific management. Both share concerned with the optima way of doing tasks and both involved programming or standardizing activities previously considered as matters of judgment. They differ, however in: management science is devoted to cognitive tasks involving information-processing activities that were becoming more and more important in the knowledge-based work in organizations.

Operations research and management science - distinct: management science is a term referring more specifically to application of quantitative techniques to management problems; it is more application-and-problem-oriented to management. Operations research is more general and theoretical in its orientation. In management science, the principal tool is no longer the stopwatch of time-and-motion study but the high-speed computer which made programmable decisions that have been previously left to human judgment and discretion.

The commonality of management science and scientific management:

1. Both represented analytical ways to decompose complex problems into component part and then reconstitute them in an orderly fashion;

2. Both were singularly focused on making analytically sound decisions, and pursuing this goal took decisions away from those who historically both made and implemented them.

Visionary Leadership The 4th set of managerial ideas emerged in recent years. It was spawned by the winds of global competition and relative decline in the efficiency of the manufacturing sector. These ideas emphasize that organizations need leadership, not just management. The basic premise is: businesses need to make fundamental changes in order to stay competitive in a rapidly changing economic environment. Leadership involves a sense of vision or mission and a capacity to inspire others to commit to its attainment, thus strategy is developed by leaders to achieve the organizational objectives. In the words of Emmerson [13] leaders don't only develop strategy. They also have strong people skills to inspire and motivate others to follow the strategy.

\section{Management Trends}

Management first evolved as the part of an economic system that allocated the resources of land, labour, and capital in a way to maximize material returns to satisfy the wants of human beings. Its primary orientation is still economic, yet, as a result of its increasing importance in society, it has become a social institution; its decisions and actions now have wide-spread impact on other institutions. Thus, management cannot escape social issues [14]. Robert [15] in his article entitled "The Importance of Modern Management Theories in Managing People," stated that modern management is the era of management that began in the 1880's and 1890s with Frederick Taylor, who argued for the abandonment of old management practices for empirically backed best practices.
To maximize productivity, managers must understand the latest best practices.

\section{CONCLUDING POINTS}

Management is an ancient practice but a new academic discipline. More than six thousand years ago the Egyptians faced the monumental management task with the construction of the pyramids, the huge public works project as the Great Wall of China, and the aqueducts that provided water to cities in the Roman Empire. Yet, only last century serious scholars sought to understand and codify the principles of effective management. It has become a synergistic field, combining aspects of many disciplines into a new and challenging field of study and practice.

By its nature, a complex phenomenon and a trans-disciplinary field of study [2]. It is a mixture of science, art, and philosophy. Science: the concepts deal primarily with the social science of administration because the systematic aspect of management relate to the concepts that can be taught and learned. Art and philosophy: products of experience and require critical self-appraisal and understanding of the organizational society in which we live.

Managers of today's organization must comprehend the essentials of individual and group behaviour if they are to motivate and communicate with others in organizations; managers need to develop their interpersonal, or people, skills to be effective in their jobs [10] must understand administrative processes if they are to plan and organize their operations; must be familiar with mathematical and statistical procedures if they are to efficiently control what goes on in organizations.

\section{REFERENCES}

[1] Abdelkarim Kitana. Overview of the managerial thoughts and theories from the history: Classical management theory to modern management theory. Indian Journal of Management Science, (6):16-21, 2016.

[2] Jack Duncan. Essentials of Management (The Dryden Press Series in Management). London: Routledge, 2009.

[3] Angus C. F. Kwok. The evolution of management theories: A literature review. Nang Yan Business Journal, 3(1):28 - 40, 2014.

[4] Alireza Nadrifar, Esmat Bandani, and Hakimeh Shahryari. Overview of classical management theories: A review article. International Journal of Science and Research (IJSR), 5(9):83 - 86, 2016.

[5] Harold Koontz and Heinz Weihrich. Essentials of Management: An International Perspective. McGraw-Hill, 8th Edition, 2010.

[6] Richard Daft. Management. South-Western College Pub; 12th Edition, 2015.

[7] Luis R. Gomez-Mejia, David B. Balkin, and Robert L. Cardy. Management: People, Performance, Change. McGraw-Hill, 2008.

[8] Andrew J. DuBrin. Essentials of Management. South-Western Learning, 2012.

[9] Dan R. Reid and Nader R. Sanders. Operations Management, An Integrated Approach. Wiley Sons Singapore Pte Ltd., 3rd Edition, 2013.

[10] Stephen P. Robbins and Timothy A.Judge. Organizational Behavior, (18th Edition) (What's New in Management). Pearson Education Limited, 2019.

[11] L. Hamilton and P Webster. The International Business Environment. Oxford University Press, 2012.

[12] Anrew Ghillyer. Management, A Real World Approach. McGrawHill, 2009.

[13] Paul Emmerson. Essential Business Vocabulary Builder. Macmillan Publishers Limited Companies, 2015. 
[14] Peter Drucker. Management: Tasks, Responsibilities, Practices. London: Routledge, 2011.

[15] Chuck Robert. The importance of modern management theories in managing people. https:/ / bizfluent.com/info-8419159importance-management-theories-managing-people.html, 2019. 